\begin{tabular}{|l|l|l||}
\hline \multicolumn{2}{|c|}{ PublisherInfo } \\
\hline \hline PublisherName & $:$ & BioMed Central \\
\hline \hline PublisherLocation & $:$ & London \\
\hline \hline PublisherImprintName & $:$ & BioMed Central \\
\hline \hline
\end{tabular}

\title{
SNPs by SPR
}

\begin{tabular}{|l|l|l||}
\hline \multicolumn{2}{|c|}{ ArticleInfo } \\
\hline \hline ArticleID & $:$ & 3949 \\
\hline \hline ArticleDOI & $:$ & $10.1186 /$ gb-spotlight-20010108-01 \\
\hline \hline ArticleCitationID & $:$ & spotlight-20010108-01 \\
\hline \hline ArticleSequenceNumber & $:$ & 20 \\
\hline \hline ArticleCategory & $:$ & Research news \\
\hline \hline ArticleFirstPage & $:$ & 1 \\
\hline \hline ArticleLastPage & $:$ & 2 \\
\hline \hline & & RegistrationDate : 2001-01-08 \\
ArticleHistory & $:$ & OnlineDate $\quad$ 2001-01-08 \\
\hline \hline ArticleCopyright & $:$ & BioMed Central Ltd2001 \\
\hline \hline ArticleGrants & $:$ & \\
\hline \hline ArticleContext & $:$ & 130592211 \\
\hline \hline
\end{tabular}




\section{William Wells}

Email: wells@biotext.com

Approximately 1.6 million single nucleotide polymorphisms (SNPs) have been identified and deposited in public databases, but more are always needed for studies of other species and identification

of mutations in candidate disease genes. In the January Nature Biotechnology, Nakatani et al. outline a new method for SNP identification using capture by a mismatch-specific ligand followed by surface plasmon resonance (SPR; Nat Biotechnol 2001, 19:51-55). The ligand, a dimeric naphthyridine, intercalates into and base-pairs with a G-G mismatch, discriminating against other mismatches. Mismatch-containing DNA is trapped by the immobilized ligand, and the DNA then changes the reflective index of polarized light hitting the SPR chip. There are disadvantages: ligands for other mismatches do not yet exist, and SPR does not identify the location of the mutation within the probed DNA fragment. But SPR can be automated, and the re-usable system requires no labeling of DNA or other probes.

\section{References}

1. Large-scale identification, mapping, and genotyping of single-nucleotide polymorphisms in the human genome.

2. A database of single nucleotide polymorphisms, [http://www.ncbi.nlm.nih.gov/SNP/]

3. Nature Biotechnology, [http://www.nature.com/nbt/]

4. BIAcore for macromolecular interaction. 